\title{
Investigation of Structural and Optical Properties of ZnO Thin Films Grown on Different Substrates by Mist-CVD Enhanced with Ozone Gas Produced by Corona Discharge Plasma
}

\author{
Ece Kutlu-Narin ${ }^{(D)},{ }^{1}$ Polat Narin $\left(\mathbb{D},{ }^{2,3}\right.$ Sefer Bora Lisesivdin $\mathbb{D D}^{2}$ \\ and Beyza Sarikavak-Lisesivdin $\mathbb{D}^{2}$ \\ ${ }^{1}$ Department of Physics Engineering, Faculty of Engineering, Ankara University, Besevler, Ankara 06100, Turkey \\ ${ }^{2}$ Department of Physics, Faculty of Science, Gazi University, Teknikokullar, Ankara 06500, Turkey \\ ${ }^{3}$ AYBU Central Research Laboratory, Application and Research Center, Ankara Yıldırım Beyazıt University, \\ Ankara 06010, Turkey
}

Correspondence should be addressed to Sefer Bora Lisesivdin; bora@gazi.edu.tr

Received 10 September 2021; Revised 9 November 2021; Accepted 10 November 2021; Published 27 November 2021

Academic Editor: Da-Ren Hang

Copyright (c) 2021 Ece Kutlu-Narin et al. This is an open access article distributed under the Creative Commons Attribution License, which permits unrestricted use, distribution, and reproduction in any medium, provided the original work is properly cited.

\begin{abstract}
This study focuses on the growth and physical properties of $\mathrm{ZnO}$ thin films on different substrates grown by mist-CVD enhanced with ozone $\left(\mathrm{O}_{3}\right)$ gas produced by corona discharge plasma using $\mathrm{O}_{2}$. Here, $\mathrm{O}_{3}$ is used to eliminate the defects related to oxygen in $\mathrm{ZnO}$ thin films. $\mathrm{ZnO}$ thin films are grown on amorphous soda-lime glass (SLG) and single crystals $\mathrm{SiO}_{2} / \mathrm{Si}(100)$ and c-plane $\mathrm{Al}_{2} \mathrm{O}_{3}$ substrates at $350^{\circ} \mathrm{C}$ of low growth temperature. All $\mathrm{ZnO}$ thin films show dominant (0002) diffraction peaks from X-ray diffraction (XRD). As expected, full width at half maximum (FWHM) of (0002) is decreasing in $\mathrm{ZnO}$ thin films on single-crystal substrates, especially c- $\mathrm{Al}_{2} \mathrm{O}_{3}$ due to similar crystal structure. It is found that the strain in the films is lowest in $\mathrm{ZnO} / \mathrm{c}-\mathrm{Al}_{2} \mathrm{O}_{3}$. The surface morphologies of the thin films are studied with atomic force microscopy (AFM) and scanning electron microscopy (SEM) measurements. Grown $\mathrm{ZnO}$ films have a hexagonal and triangular nanostructure with different nanostructure sizes depending on the used substrate types. The calculated surface roughness is dramatically decreased in $\mathrm{ZnO} / \mathrm{c}-\mathrm{Al}_{2} \mathrm{O}_{3}$ compared to the other grown structures. The confocal Raman measurements show the $E_{2}(\mathrm{H})$ peak of $\mathrm{ZnO}$ thin films at $437 \mathrm{~cm}^{-1}$. It is suggested that $\mathrm{O}_{3}$ gas produced by corona discharge plasma using $\mathrm{O}_{2}$ can be useful to obtain better crystal quality and physical properties in $\mathrm{ZnO}$ thin films.
\end{abstract}

\section{Introduction}

Zinc oxide ( $\mathrm{ZnO})$, which is one of the most studied transparent conductive oxide (TCO), is a wide bandgap semiconductor material with a $3.37 \mathrm{eV}$ bandgap value and a large exciton binding energy of $60 \mathrm{meV}[1,2]$. $\mathrm{ZnO}$ material has a huge potential for both electronic and optoelectronic applications such as light-emitting diodes (LED), solar cells, transistors, gas sensing, and UV-photodetectors (PDs) [3-11]. In the last decade, bulk $\mathrm{ZnO}$ and its related heterostructures and many probable nanostructures have been investigated by different experimental techniques because of the possibility that a wide range of applications can be done with them [12-14].
The $\mathrm{ZnO}$ thin films can be prepared by various techniques such as the sol-gel method, spray pyrolysis, molecular beam epitaxy (MBE), and metal-organic chemical vapor deposition (MOCVD) growth method [15-18]. Concerning many different types of chemical vapor deposition, ultrasonic spray or mist chemical vapor deposition (USCVD or mist-CVD) can be accepted as a new technology for growing oxide semiconductors [19-21]. Several studies used mist-CVD as a growth method and have successfully shown that the procedure allows low-cost, easy maintenance, simple system configuration, and highquality semiconductor oxide films $[22,23]$. Because the types of mist-CVD growth systems and used parameters 
are still a subject of research, there are many important questions about the growth mechanism and the related chemical processes that need to be answered.

In general, the mist-CVD growth method can be controlled by reactor temperature, frequency, and voltage of the ultrasonic transducer, growth time, precursor molarity, carrier gas flow rate, and carrier gas type. Previously, the usage of oxygen $\left(\mathrm{O}_{2}\right)$, argon $(\mathrm{Ar})$, and nitrogen $\left(\mathrm{N}_{2}\right)$ as a carrier gas was reported in some studies [24-26]. In addition to these carrier gases, hydrogen peroxide $\left(\mathrm{H}_{2} \mathrm{O}_{2}\right)$ can be used as an oxidant in $\mathrm{ZnO}$ growths [27]. Also, the usage of ozone gas as an oxidant in MBE, ALD, and MOCVDgrown $\mathrm{ZnO}$ crystals is a known process $[27,28]$. In $\mathrm{ZnO}$ thin film growths, some known structural defects or disorders such as $\mathrm{Zn}$ vacancy $\left(\mathrm{V}_{\mathrm{Zn}}\right)$, O vacancy $\left(\mathrm{V}_{0}\right)$, or interstitial of $\mathrm{O}$ and $\mathrm{Zn}$ atoms can occur. These defects can give rise to the poor physical properties at $\mathrm{ZnO}$, especially in both electronic and optical properties. Among these defects, the $V_{\mathrm{o}}$ defect is unintentionally formed in the crystal without doping and has a luminescence of about $500 \mathrm{~nm}$ that is called green luminescence. To minimize these defects in the lattice system, especially $V_{\mathrm{o}}, \mathrm{O}_{3}$ is used as an oxygen source in the MBE system, and more oriented $\mathrm{ZnO}$ films can be obtained [29]. $\mathrm{O}_{3}$-rich growth could be better than conventional using $\mathrm{O}_{2}$ to oxidize the $\mathrm{Zn}$ metal in the precursor. Also, in this study, $\mathrm{ZnO}$ thin films are on different substrates $\mathrm{SLG}, \mathrm{SiO}_{2} / \mathrm{p}-\mathrm{Si}(100)$, and $\mathrm{c}-\mathrm{Al}_{2} \mathrm{O}_{3}$ by mist-CVD with $\mathrm{O}_{3}$-rich $\mathrm{O}_{2}$ gas where $\mathrm{O}_{3}$ gas is generated by a corona discharge generator. The structural and optical properties of the grown thin films are studied by X-ray diffraction (XRD), atomic force microscope (AFM), scanning electron microscope (SEM) \, and confocal Raman spectroscopy measurements.

\section{Experimental Details}

$\mathrm{ZnO}$ thin films were grown by the mist-CVD method on soda-lime glass (SLG), $\mathrm{SiO}_{2} / \mathrm{p}-\mathrm{Si}$, and c- $\mathrm{Al}_{2} \mathrm{O}_{3}$ substrates. As a source material of $\mathrm{ZnO}$, zinc acetate dihydrate salt ( $\mathrm{ZnAc})$, which has the chemical formula $\mathrm{Zn}\left(\mathrm{CH}_{3} \mathrm{COO}\right)_{2} \cdot 2 \mathrm{H}_{2} \mathrm{O}$, was used. The deposition parameters of $\mathrm{ZnO}$ thin films are given in Table 1. The substrates were first cleaned with acetone, ethanol, and deionized water (DIW), respectively. All substrates were dried in the $\mathrm{N}_{2}$ atmosphere. Samples were named $\mathrm{A}, \mathrm{B}$, and $\mathrm{C}$ according to $\mathrm{ZnO}$ grown on $\mathrm{SLG}, \mathrm{SiO}_{2} / \mathrm{p}$ $\mathrm{Si}(100)$, and $\mathrm{c}-\mathrm{Al}_{2} \mathrm{O}_{3}$ substrates, respectively. The $90 \mathrm{~nm}$ thick $\mathrm{SiO}_{2}$ is formed by thermal oxidation on the p-Si substrate. XRD measurements were done using a Rigaku SmartLab with $\mathrm{CuK} \alpha 1.54 \AA$ of the X-ray wavelength. To determine the morphological structure and growth mode, AFM (AFM workshop TT-2) and SEM (Hitachi SU 5000) measurements were taken. Confocal Raman measurement was carried out using the Jasco NRS-4500 system with a $532 \mathrm{~nm}$ green laser.

Figure 1 shows the mist-CVD system used in $\mathrm{ZnO}$ thin film growth. The mist-CVD system was enhanced with a corona discharge plasma generator. The $\mathrm{O}_{2}$ came from the gas flowmeter going into the plasma generator and $\mathrm{O}_{3}$ riched gas from the generator goes into the reactor as an
TABLE 1: Mist-CVD deposition parameters for $\mathrm{ZnO}$ thin films.

\begin{tabular}{lc}
\hline Parameters & Values \\
\hline Growth temperature $\left({ }^{\circ} \mathrm{C}\right)$ & 350 \\
Growth time (min) & 30 \\
Carrier gas flow rate (L/min) & 5 \\
Ultrasonic transducer power $(\mathrm{W})$ & 8 \\
Precursor molarity $(\mathrm{M})$ & 0.05 \\
Quartz reactor diameter (inch) & 2 \\
\hline
\end{tabular}

oxidation source in this system. $\mathrm{O}_{3}$-riched gas is generally formed according to the following equations.

$$
\begin{aligned}
\mathrm{O}_{2} & \leftrightarrow O^{-}+O^{-}, \\
2 \mathrm{O}_{2}+\mathrm{O}^{-} & \leftrightarrow \mathrm{O}_{3}+\mathrm{O}_{2} .
\end{aligned}
$$

The liquid precursor using an ultrasonic transducer has become a cold mist vapor, and the formed mist vapor with $\mathrm{O}_{3}$-riched gas goes to a hot-wall CVD reactor. A polypropylene (PP) film was used between the ultrasonic transducer and liquid precursor to avoid damaging the transducer from acetic acid. After the decomposition process of mist particles, $\mathrm{ZnO}$ nucleation layers are formed and then turned into thin films on the substrate surface.

\section{Results and Discussion}

XRD measurements of investigated structures have been carried out as shown in Figure 2. According to XRD results, $\mathrm{ZnO}$ thin films are preferentially grown in a wurtzite hexagonal crystal system without any other crystal phases. Three well-defined $\mathrm{ZnO}$ peaks have been seen, displayed as the (10$10)$, (0002), and (10-11) peaks showing the $\mathrm{ZnO}$ polycrystalline wurtzite structure. As can be seen, all the samples are oriented in the dominant (0002) direction. The (0002) peak position of $\mathrm{ZnO}$ thin films has been gradually shifted to the higher diffraction angles when the used substrate can become different from the crystal system of $\mathrm{ZnO}$ and thus lead to strained $\mathrm{ZnO}$ structures.

All investigated $\mathrm{ZnO}$ thin films show the compressive strain. The strain calculation was carried out via $\varepsilon_{z z}=\left(c_{0^{-}} c\right) /$ $c_{0}$, where $c_{0}$ is the lattice parameter of $\mathrm{ZnO}$ without strain [30]. From the relevant XRD peak results, to observe the crystallite size of the samples, Scherrer's formula has been used as given in equation (2).

$$
\begin{aligned}
D & =\frac{0.89 \lambda}{\beta \cos \theta}, \\
\frac{1}{d_{h k l}^{2}} & =\frac{4}{3}\left(\frac{h^{2}+h k+k^{2}}{a^{2}}\right)+\frac{l^{2}}{c^{2}},
\end{aligned}
$$

where $D$ is the crystallite size, $\beta$ is the full width at half maximum (FWHM), $\lambda$ is the wavelength of $\mathrm{X}$-ray equal to $0.154 \mathrm{~nm}$, and $\theta$ is the peak location of (0002) diffraction.

The AFM images of the investigated $\mathrm{ZnO}$ thin films are shown in Figure 3. The surface morphology of $\mathrm{ZnO}$ thin films is different from each other due to using different types of substrates. As can be seen, the lower surface roughness 


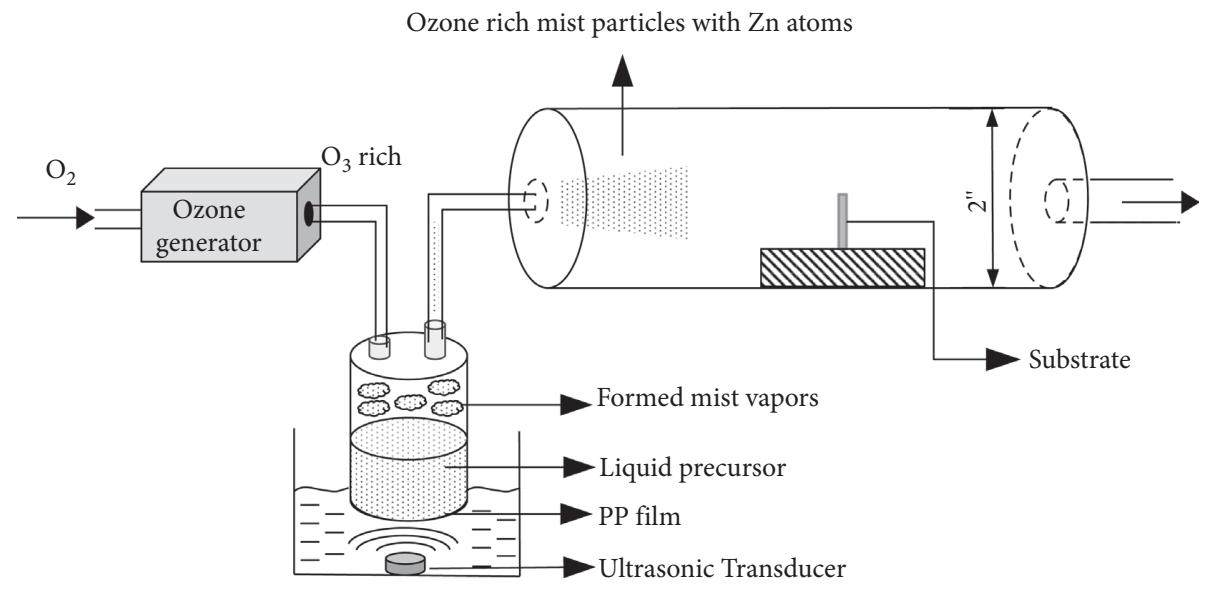

FIgure 1: The illustration of the mist-CVD growth system.

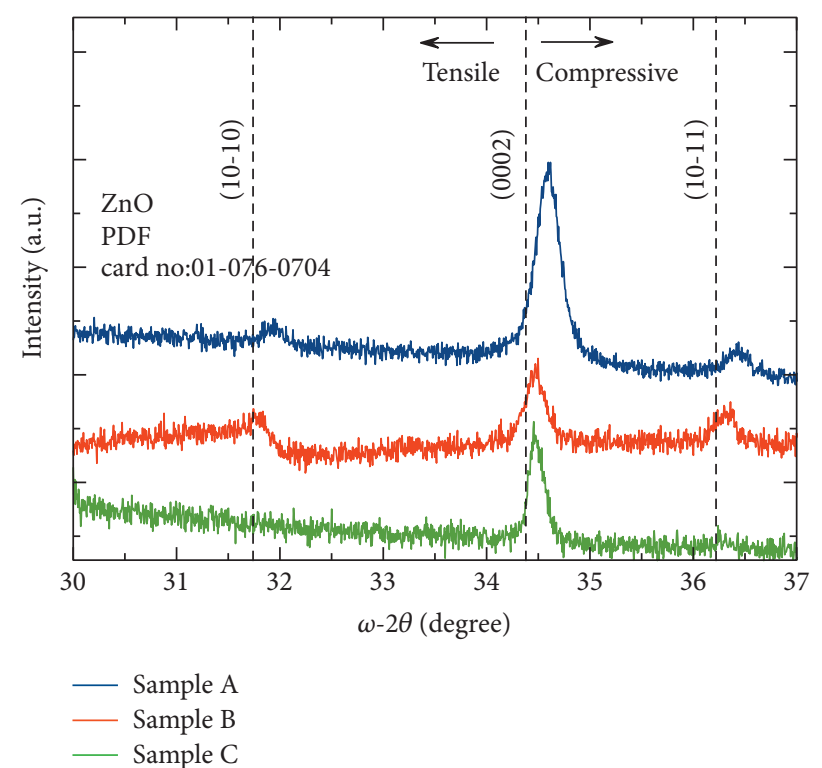

Figure 2: XRD patterns of samples A, B, and C.

parameter is found in $\mathrm{ZnO} / \mathrm{c}-\mathrm{Al}_{2} \mathrm{O}_{3}$ with a $15.3 \mathrm{~nm}$ root mean square (RMS). The RMS values of $\mathrm{ZnO} / \mathrm{SLG}$ and $\mathrm{ZnO} /$ $\mathrm{SiO}_{2} / \mathrm{p}$-Si are calculated as $43.6 \mathrm{~nm}$ and $37.3 \mathrm{~nm}$, respectively. In addition, the surface amplitude values from surface height profiles of $\mathrm{ZnO}$ thin films are high in $\mathrm{ZnO} / \mathrm{SLG}$ and $\mathrm{ZnO} / \mathrm{SiO}_{2} / \mathrm{Si}$ and that of $\mathrm{ZnO} / \mathrm{c}-\mathrm{Al}_{2} \mathrm{O}_{3}$ is below $10 \mathrm{~nm}$, even it can be found in very small values in some regions on the line. In literature, RMS values for 200 and $90 \mathrm{~nm}$ thickness of $\mathrm{ZnO}$ on quartz substrate were found as $14.49 \mathrm{~nm}$ and $14.35 \mathrm{~nm}$, respectively, using the mist-CVD method [31], and an RMS value for $98 \mathrm{~nm}$ thick $\mathrm{ZnO}$ thin films grown by the sol-gel process is found to be $5.8 \mathrm{~nm}$ [32]. Our results are found to agree with these literature values.

Figure 4 shows the top-view SEM images of $\mathrm{ZnO}$ thin films with $\mathrm{x} 20 \mathrm{k}$ and $\mathrm{x} 90 \mathrm{k}$ magnification. Very homogeneous surface structures are seen in SEM images for each $\mathrm{ZnO}$ film. $\mathrm{ZnO}$ thin films have preferred to grow in triangular and hexagonal formed nanopyramids as can be seen from SEM images. These hexagonal and triangular pyramids are randomly grown on the substrate surface especially for sample A, and this results in polycrystalline hexagonal structure as shown in XRD results. These pyramid forms of $\mathrm{ZnO}$ can be found in the literature [33-35]. The thicknesses of $\mathrm{ZnO}$ thin films are determined with cross-sectional SEM images as shown in Figure 5. The thickness of films ranges from $90 \mathrm{~nm}$ to $180 \mathrm{~nm}$ according to cross-sectional SEM images. $\mathrm{ZnO}$ films grown on single crystals have shown more uniform growing behaviors rather than $\mathrm{ZnO}$ grown on SLG. In our previous $\mathrm{ZnO}$ growths, we have a problem related to island-type growth like noncontinued film; however, after using $\mathrm{O}_{3}$-riched gas as the carrier gas, it is shown that these growths begin to grow the continued thin film also as shown in Figure $5[36,37]$. Moreover, $\mathrm{ZnO} / \mathrm{c}$ $\mathrm{Al}_{2} \mathrm{O}_{3}$ films are highly oriented with columnar-like dense growth. Such columnar $\mathrm{ZnO}$ growths are known to have light-trapping properties in solar cells applications [38].

The vibration properties of $\mathrm{ZnO}$ thin films are investigated with confocal Raman spectroscopy measurement. The 

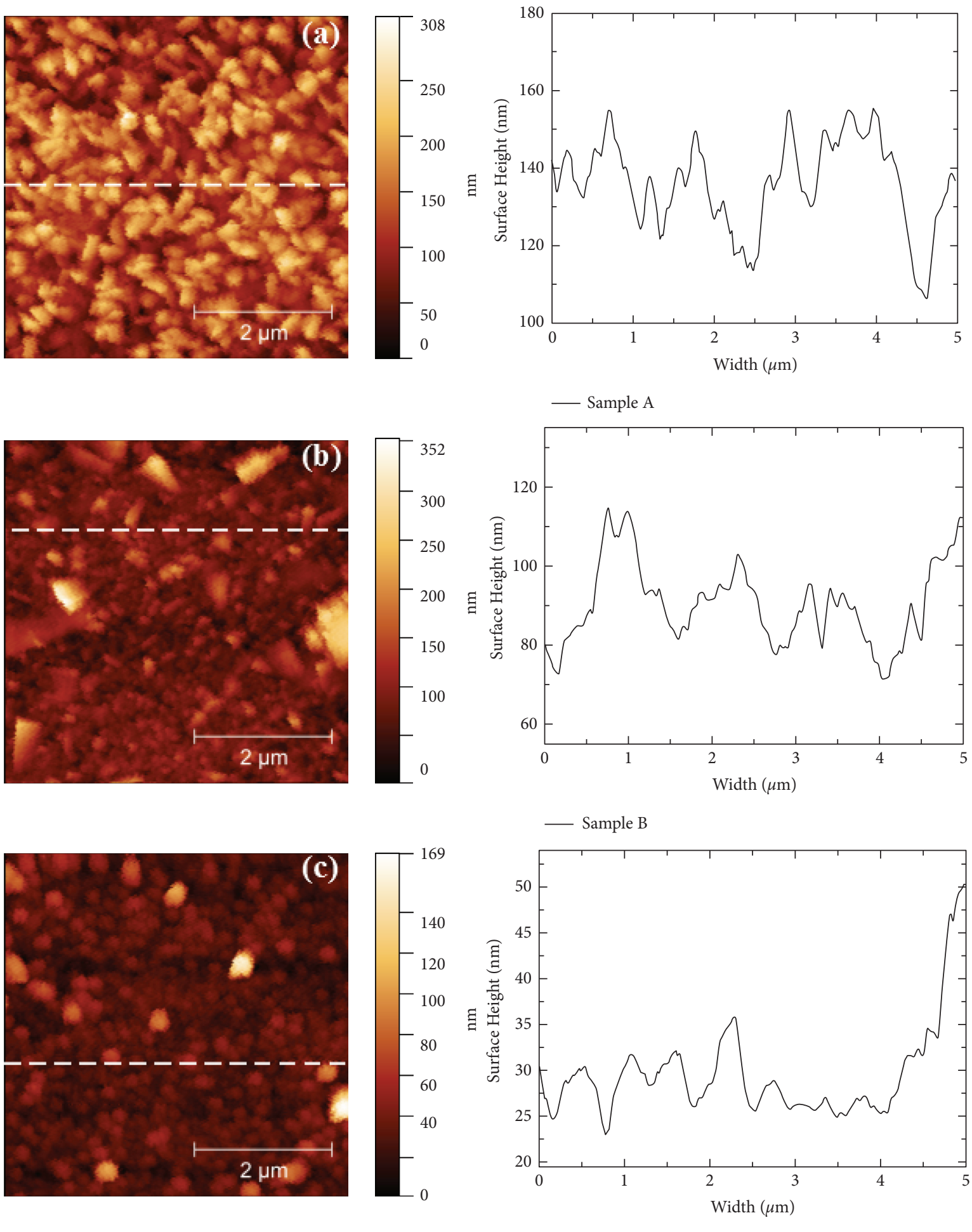

- Sample C

Figure 3: AFM images of samples (a) A, (b) B, and (c) C for $5 \times 5 \mu \mathrm{m}^{2}$. Dashed lines represent the surface height of films.

optical vibration modes at $\Gamma$ points of the Brillouin zone of hexagonal wurtzite $\mathrm{ZnO}$ can be written as $\Gamma_{o p t}=A_{1}+2 B_{1}+E_{1}+2 E_{2} \quad$ [39]. All samples exhibited the wurtzite $\mathrm{ZnO}$ phase according to Raman measurement. While $B_{1}$ is Raman-inactive mode, $A_{1}, E_{1}$, and $E_{2}$ are Ramanactive modes. Each $\mathrm{ZnO}$ thin film exhibits the high- frequency $E_{2}(H)$ mode which means vibration of $\mathrm{O}$ atoms in the lattice at 428,435 , and $437 \mathrm{~cm}^{-1}$ for $\mathrm{ZnO} / \mathrm{SLG}, \mathrm{ZnO} /$ $\mathrm{SiO}_{2} / \mathrm{Si}$, and $\mathrm{ZnO} / \mathrm{c}-\mathrm{Al}_{2} \mathrm{O}_{3}$ structures, respectively. The Raman peak of $E_{2}(H)$ of $\mathrm{ZnO}$ on these different substrates are found to shift to red with respect to $438 \mathrm{~cm}^{-1}$ peak of $E_{2}(H)$ of single-crystal $\mathrm{ZnO}$. The high-frequency $E_{2}(L)$ 


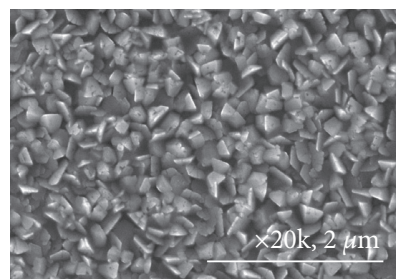

(a)

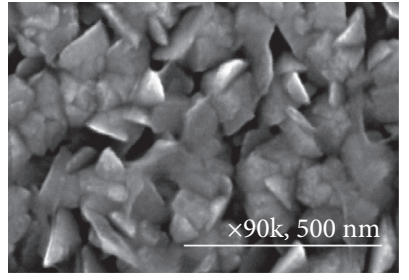

(d)

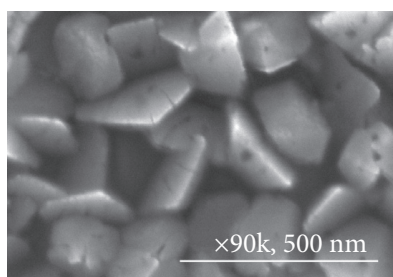

(b)

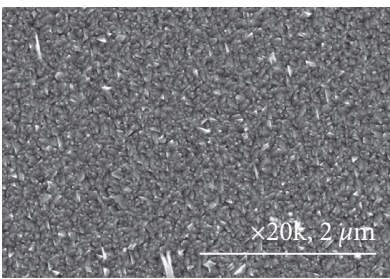

(e)

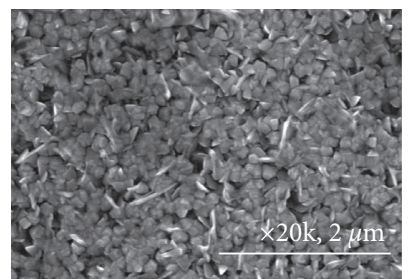

(c)

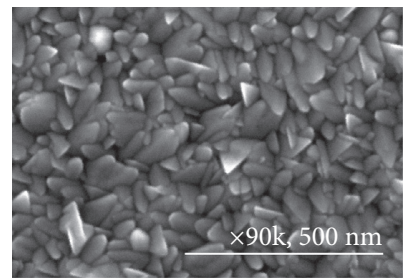

(f)

Figure 4: Top-view SEM images of ZnO thin films. (a)-(b) Sample A, (c)-(d) sample B, and (e)-(f) sample C.
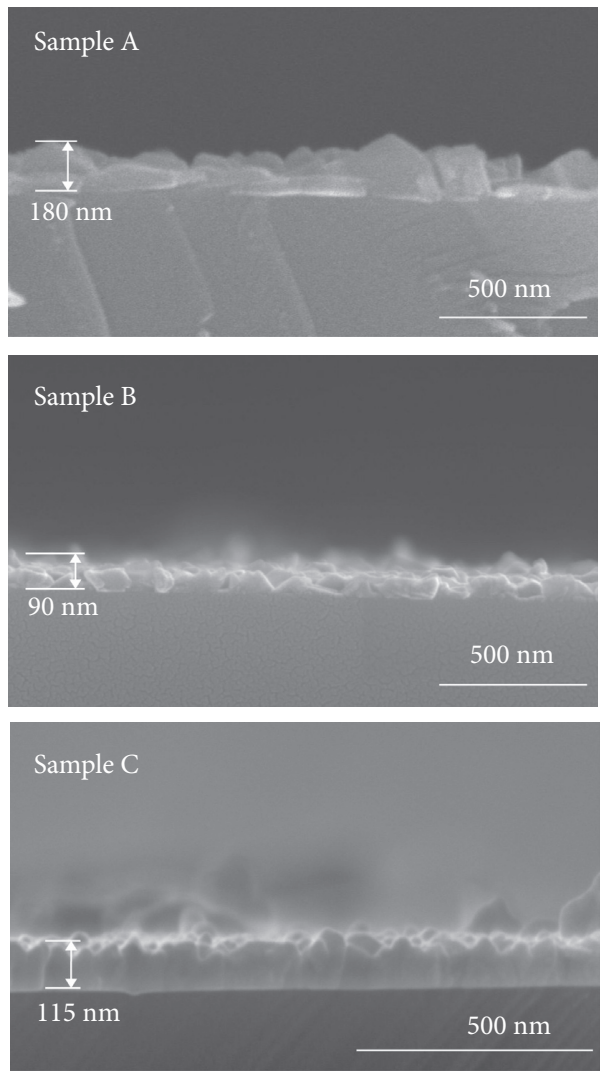

FIgURE 5: Cross-sectional SEM images of samples A, B, and C.

Raman peaks, which are related to $\mathrm{Zn}$ vibration, are presented at 97 and $99 \mathrm{~cm}^{-1}$ for $\mathrm{ZnO} / \mathrm{SiO}_{2} / \mathrm{Si}$ and $\mathrm{ZnO} / \mathrm{c}-\mathrm{Al}_{2} \mathrm{O}_{3}$, respectively. Also, for the grown $\mathrm{ZnO}$ thin films, the substrate-related Raman peaks are shown for $\mathrm{SiO}_{2} / \mathrm{Si}$ and c- $\mathrm{Al}_{2} \mathrm{O}_{3}$ substrates as shown in Figure 6. In some $\mathrm{ZnO}$ thin films, multiple-phonon vibration modes are also observed. For sample A, the second-order peak of the longitudinal acoustic (LA) mode, which is related to LA overtones in the
M-K zone, is observed at $483 \mathrm{~cm}^{-1}$ [40]. Some structural and vibrational parameters of the investigated $\mathrm{ZnO}$ thin films from AFM, XRD, and Raman measurements are given in Table 2.

The peak shifts of the $E_{2}(H)$ Raman and (0002) direction of the XRD spectra are shown in Figure 7. $\Delta \omega$ and $\Delta \theta$ are the peak shift values in the Raman and XRD spectra, respectively. $\Delta \omega$ values in the $E_{2}(H)$ Raman spectrum are found to 


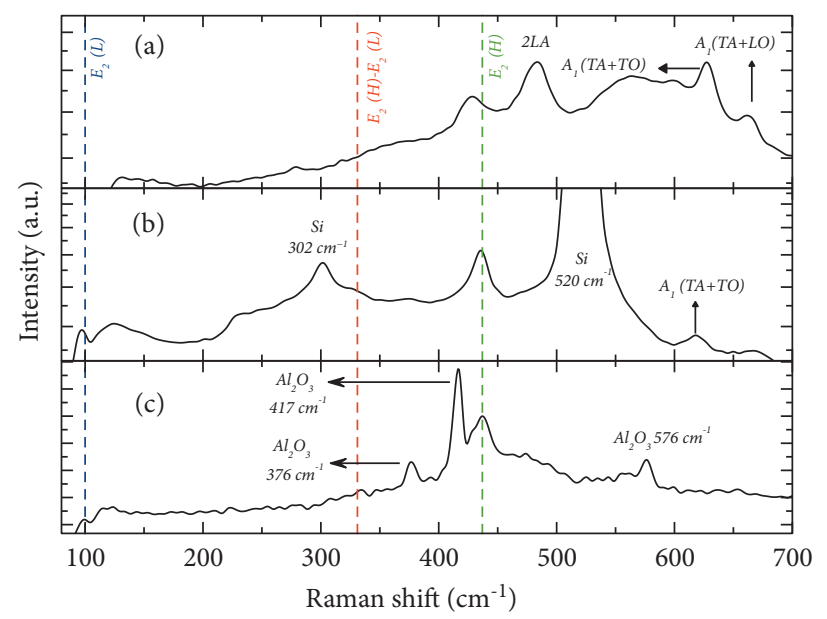

Figure 6: The Raman spectrum of samples (a) A, (b) B, and (c) C.

TABLE 2: Structural and vibrational properties of $\mathrm{ZnO}$ thin films.

\begin{tabular}{|c|c|c|c|c|c|c|c|}
\hline Samples & Interplanar spacing $d(\mathrm{~nm})$ & Lattice parameter $c(\mathrm{~nm})$ & Crystallite size $(\mathrm{nm})$ & Strain $\left(\varepsilon_{\mathrm{zz}}\right)$ & RMS (nm) & $E_{2}(\mathrm{~L})\left(\mathrm{cm}^{-1}\right)$ & $\begin{array}{c}E_{2}(\mathrm{H}) \\
\left(\mathrm{cm}^{-1}\right)\end{array}$ \\
\hline A & 0.2588 & 0.5176 & 29.58 & -0.0045 & 43.6 & - & 428 \\
\hline B & 0.2596 & 0.5193 & 36.87 & -0.0012 & 37.3 & 97 & 435 \\
\hline $\mathrm{C}$ & 0.2599 & 0.5199 & 46.71 & -0.0006 & 15.3 & 99 & 437 \\
\hline
\end{tabular}
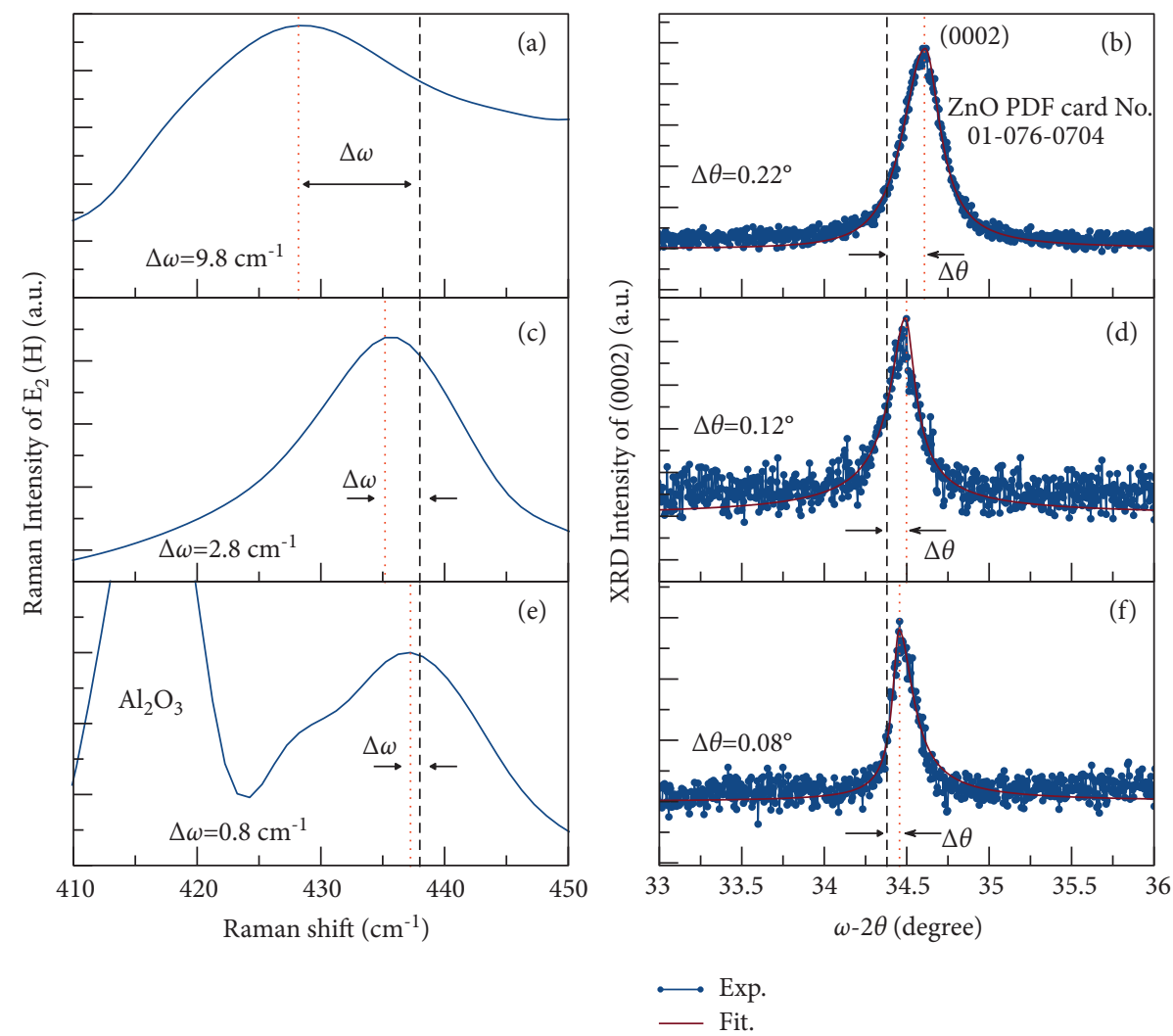

FIGURE 7: Investigation of shifts in $E_{2}(H)$ of Raman and (0002) direction of XRD spectra. (a)-(b) Sample A, (c)-(d) sample B, and (e)-(f) sample C. 
TABLE 3: The peak shifts of Raman and XRD peaks and calculated strain values of $\mathrm{ZnO}$ thin films.

\begin{tabular}{lccc}
\hline Samples & $\Delta \theta($ degree $)$ & $\Delta \omega\left(\mathrm{cm}^{-1}\right)$ & Strain $\left(\varepsilon_{\mathrm{zz}}\right)$ \\
\hline $\mathrm{A}$ & 0.22 & 9.8 & -0.0045 \\
$\mathrm{~B}$ & 0.12 & 2.8 & -0.0012 \\
$\mathrm{C}$ & 0.08 & 0.8 & -0.0006 \\
\hline
\end{tabular}

be $9.8,2.8$, and $0.8 \mathrm{~cm}^{-1}$ for samples $\mathrm{A}, \mathrm{B}$, and $\mathrm{C}$, respectively, and also, $\Delta \theta$ values are determined as $0.22,0.12$, and 0.08 for samples A, B, and C, respectively, as given in Table 3 . One of the causes of the strain is the lattice-mismatch between $\mathrm{ZnO}$ and substrates. With a decreasing lattice mismatch, the redshift of $E_{2}(H)$ is gradually decreased with a reduction of local strain in the $\mathrm{ZnO}$ lattice which shows a decrease in $\Delta \theta$ values.

\section{Conclusion}

In the present study, $\mathrm{ZnO}$ thin films have been grown via mist-CVD enhanced with $\mathrm{O}_{3}$ gas produced by corona discharge plasma using $\mathrm{O}_{2}$. The continuous $\mathrm{ZnO}$ films are obtained on the substrate surfaces. Grown $\mathrm{ZnO}$ films are mostly preferred in (0002) direction and have a polycrystalline pyramid-like structure. The island-like growing behavior in mist-CVD grown polycrystals has changed to smooth columnar-type growth after using $\mathrm{O}_{3}$-riched gas. The surface roughness of $\mathrm{ZnO}$ thin films is gradually decreased from using amorphous to hexagonal substrates. The wurtzite-type $\mathrm{ZnO}$ thin film formation is also supported with Raman spectroscopy. The characteristic $\mathrm{ZnO}$ vibration modes and the peak shifts of these modes due to usage of different substrates are shown. The redshifts of the $E_{2}(H)$ mode in the Raman spectrum are observed to decrease as the strain declines in the $\mathrm{ZnO}$ thin film.

\section{Data Availability}

The data used to support the findings of this study are available from the corresponding author upon request.

\section{Conflicts of Interest}

The authors declare that they have no conflicts of interest.

\section{Acknowledgments}

This work was supported by TUBITAK (116F197). S. B. L. was supported in part by the Distinguished Young Scientist Award of the Turkish Academy of Sciences (TUBAGEBIP 2016).

\section{References}

[1] D. M. Bagnall, Y. F. Chen, Z. Zhu et al., "Optically pumped lasing of $\mathrm{ZnO}$ at room temperature," Applied Physics Letters, vol. 70, no. 17, pp. 2230-2232, 1997.

[2] P. Yu, Z. K. Tang, G. K. L. Wong et al., "Room-temperature gain spectra and lasing in microcrystalline $\mathrm{ZnO}$ thin films," Journal of Crystal Growth, vol. 184-185, pp. 601-604, 1998.
[3] H. Cao, J. Y. Xu, D. Z. Zhang et al., "Spatial confinement of laser light in active random media," Physical Review Letters, vol. 84, no. 24, pp. 5584-5587, 2000.

[4] A. Qurashi, N. Tabet, M. Faiz, and T. Yamzaki, "Ultra-fast microwave synthesis of $\mathrm{ZnO}$ nanowires and their dynamic response toward hydrogen gas," Nanoscale research letters, vol. 4, no. 8, pp. 948-954, 2009.

[5] L.-J. Bie, X.-N. Yan, J. Yin, Y.-Q. Duan, and Z.-H. Yuan, "Nanopillar $\mathrm{ZnO}$ gas sensor for hydrogen and ethanol," Sensors and Actuators B: Chemical, vol. 126, no. 2, pp. 604608, 2007.

[6] O. Lupan, G. Chai, and L. Chow, "Fabrication of $\mathrm{ZnO}$ nanorod-based hydrogen gas nanosensor," Microelectronics Journal, vol. 38, no. 12, pp. 1211-1216, 2007.

[7] J. Xiao, "Growth and field emission properties of chessmanlike and tower-like $\mathrm{ZnO}$ nanostructures," Materials Chemistry and Physics, vol. 115, no. 2-3, pp. 771-774, 2009.

[8] M. Ahmad, C. Pan, J. Zhao, J. Iqbal, and J. Zhu, "Electron irradiation effect and photoluminescence properties of $\mathrm{ZnO}$ tetrapod nanostructures," Materials Chemistry and Physics, vol. 120, no. 2-3, pp. 319-322, 2010.

[9] X. Chen, Q. Xie, and J. Li, "Significantly improved photoluminescence properties of $\mathrm{ZnO}$ thin films by lithium doping," Ceramics International, vol. 46, no. 2, pp. 2309-2316, 2020.

[10] H. Wu, J. Ding, D. Yang, J. Li, Y. Shi, and Y. Zhou, "Graphene quantum dots doped $\mathrm{ZnO}$ superstructure ( $\mathrm{ZnO}$ superstructure/GQDs) for weak UV intensity photodetector application," Ceramics International, vol. 46, no. 11, pp. 17800-17808, 2020.

[11] J. Li, X. Zhu, Q. Xie, and D. Yang, "Surface nanosheets evolution and enhanced photoluminescence properties of Aldoped $\mathrm{ZnO}$ films induced by excessive doping concentration," Ceramics International, vol. 45, no. 3, pp. 3871-3877, 2019.

[12] K. Hara, T. Horiguchi, T. Kinoshita, K. Sayama, H. Sugihara, and H. Arakawa, "Highly efficient photon-to-electron conversion with mercurochrome-sensitized nanoporous oxide semiconductor solar cells," Solar Energy Materials and Solar Cells, vol. 64, no. 2, pp. 115-134, 2000.

[13] J. Huang, Y. Wu, C. Gu, M. Zhai, Y. Sun, and J. Liu, "Fabrication and gas-sensing properties of hierarchically porous $\mathrm{ZnO}$ architectures," Sensors and Actuators B: Chemical, vol. 155, no. 1, pp. 126-133, 2011.

[14] D.-K. Hwang, S.-H. Kang, J.-H. Lim et al., "p-ZnO/n-GaN heterostructure $\mathrm{ZnO}$ light-emitting diodes," Applied Physics Letters, vol. 86, no. 22, p. 222101, 2005.

[15] J. Li, J. Wang, Y. Pei, and G. Wang, "Study on the uniformity of $\mathrm{ZnO}$ films grown by MOCVD," Ceramics International, vol. 45, no. 11, pp. 13971-13978, 2019.

[16] K. Mahmood and B. M. Samaa, "Influence of annealing treatment on structural, optical, electric, and thermoelectric properties of MBE-grown ZnO," Journal of Experimental and Theoretical Physics, vol. 126, no. 6, pp. 766-771, 2018.

[17] O. Bazta, A. Urbieta, J. Piqueras et al., "Influence of yttrium doping on the structural, morphological and optical properties of nanostructured $\mathrm{ZnO}$ thin films grown by spray pyrolysis," Ceramics International, vol. 45, no. 6 , pp. 6842-6852, 2019.

[18] Q. Fan, D. Li, J. Li, and C. Wang, "Structure and piezoelectricity properties of $\mathrm{V}$-doped $\mathrm{ZnO}$ thin films fabricated by sol-gel method," Journal of Alloys and Compounds, vol. 829, p. $154483,2020$.

[19] M. Girtan and G. Folcher, "Structural and optical properties of indium oxide thin films prepared by an ultrasonic spray 
CVD process," Surface and Coatings Technology, vol. 172, no. 2-3, pp. 242-250, 2003.

[20] B.-H. Kim, J.-Y. Lee, Y.-H. Choa, M. Higuchi, and N. Mizutani, "Preparation of $\mathrm{TiO} 2$ thin film by liquid sprayed mist CVD method," Materials Science and Engineering: B, vol. 107, no. 3, pp. 289-294, 2004.

[21] J. G. Lu, T. Kawaharamura, H. Nishinaka, Y. Kamada, T. Ohshima, and S. Fujita, "ZnO-based thin films synthesized by atmospheric pressure mist chemical vapor deposition," Journal of Crystal Growth, vol. 299, no. 1, pp. 1-10, 2007.

[22] H. Nishinaka, T. Kawaharamura, and S. Fujita, "Low-temperature growth of $\mathrm{ZnO}$ thin films by linear source ultrasonic spray chemical vapor deposition," Japanese Journal of Applied Physics, vol. 46, no. 10R, p. 6811, 2007.

[23] T. Kawaharamura, "Physics on development of open-air atmospheric pressure thin film fabrication technique using mist droplets: control of precursor flow," Japanese Journal of Applied Physics, vol. 53, no. 5S1, p. 05FF08, 2014.

[24] H.-J. Jeon, S.-G. Lee, K.-S. Shin, S.-W. Kim, and J.-S. Park, "Growth behaviors and film properties of zinc oxide grown by atmospheric mist chemical vapor deposition," Journal of Alloys and Compounds, vol. 614, pp. 244-248, 2014.

[25] S. Saini, P. Mele, T. Oyake et al., "Porosity-tuned thermal conductivity in thermoelectric Al-doped $\mathrm{ZnO}$ thin films grown by mist-chemical vapor deposition," Thin Solid Films, vol. 685, pp. 180-185, 2019.

[26] H. Nishinaka and S. Fujita, "Step-flow growth of homoepitaxial $\mathrm{ZnO}$ thin films by ultrasonic spray-assisted MOVPE," Journal of Crystal Growth, vol. 310, no. 23, pp. 5007-5010, 2008.

[27] J. Park, T.-H. Jung, J.-H. Lee, H.-S. Kim, and J.-S. Park, “The growth behavior and properties of atomic layer deposited zinc oxide films using hydrogen peroxide (H2O2) and ozone (O3) oxidants," Ceramics International, vol. 41, no. 1 , pp. 1839-1845, 2015.

[28] M. Fujita, N. Kawamoto, T. Tatsumi, K. Yamagishi, and Y. Horikoshi, "Molecular beam epitaxial growth of $\mathrm{ZnO}$ on $\mathrm{Si}$ substrate using ozone as an oxygen source," Japanese Journal of Applied Physics, vol. 42, no. 1R, p. 67, 2003.

[29] Y. W. Heo, K. Ip, S. J. Pearton, D. P. Norton, and J. D. Budai, "Growth of $\mathrm{ZnO}$ thin films on c-plane $\mathrm{Al} 2 \mathrm{O} 3$ by molecular beam epitaxy using ozone as an oxygen source," Applied Surface Science, vol. 252, no. 20, pp. 7442-7448, 2006.

[30] R. R. Reeber, "Lattice parameters of $\mathrm{ZnO}$ from $4.2^{\circ}$ to $296^{\circ} \mathrm{K}$," Journal of Applied Physics, vol. 41, no. 13, pp. 5063-5066, 1970.

[31] T. Kawaharamura, H. Orita, T. Shirahata, A. Yoshida, S. Fujita, and T. Hirao, "Influence of annealing under reducing ambient on properties of $\mathrm{ZnO}$ thin films prepared by mist CVD," Physica Status Solidi C, vol. 9, no. 2, pp. 190-193, 2012.

[32] V. Kumar, N. Singh, R. M. Mehra, A. Kapoor, L. P. Purohit, and H. C. Swart, "Role of film thickness on the properties of $\mathrm{ZnO}$ thin films grown by sol-gel method," Thin Solid Films, vol. 539, pp. 161-165, 2013.

[33] Y. Tian, H.-B. Lu, J.-C. Li, Y. Wu, and Q. Fu, "Synthesis, characterization and photoluminescence properties of $\mathrm{ZnO}$ hexagonal pyramids by the thermal evaporation method," Physica E: Low-Dimensional Systems and Nanostructures, vol. 43, no. 1, pp. 410-414, 2010.

[34] X. Zhou, Z.-X. Xie, Z.-Y. Jiang et al., "Formation of $\mathrm{ZnO}$ hexagonal micro-pyramids: a successful control of the exposed polar surfaces with the assistance of an ionic liquid," Chemical Communications, vol. 44, pp. 5572-5574, 2005.
[35] P. K. Samanta and S. Basak, "Electrochemical growth of hexagonal $\mathrm{ZnO}$ pyramids and their optical property," $M a$ terials Letters, vol. 83, pp. 97-99, 2012.

[36] P. Narin, E. Kutlu-Narin, and S. B. Lisesivdin, "Growth dynamics of mist-CVD grown $\mathrm{ZnO}$ nanoplatelets," Physica B: Condensed Matter, vol. 614, p. 413028, 2021.

[37] P. Narin, E. Kutlu, G. Atmaca, A. Atilgan, A. Yildiz, and S. B. Lisesivdin, "Structural and optical properties of hexagonal $\mathrm{ZnO}$ nanostructures grown by ultrasonic spray CVD," Optik, vol. 168, pp. 86-91, 2018.

[38] T. Shinagawa, K. Shibata, O. Shimomura, M. Chigane, R. Nomura, and M. Izaki, "Solution-processed high-haze $\mathrm{ZnO}$ pyramidal textures directly grown on a TCO substrate and the light-trapping effect in Cu2O solar cells," Journal of Materials Chemistry C, vol. 2, no. 16, pp. 2908-2917, 2014.

[39] C. A. Arguello, D. L. Rousseau, and S. P. S. Porto, "First-order Raman effect in wurtzite-type crystals," Physical Review, vol. 181, no. 3, pp. 1351-1363, 1969.

[40] R. Cuscó, E. Alarcón-Lladó, J. Ibanez et al., "Temperature dependence of Raman scattering in $\mathrm{ZnO}$," Physical Review B, vol. 75, no. 16, p. 165202, 2007. 